\title{
Efek Sitotoksik Ekstrak dan Fraksi Umbi Paku Atai Merah (Angiopteris ferox Copel) Terhadap Sel Kanker Payudara T47D
}

\section{(Cytotoxic Effects of Paku Atai Merah (Angiopteris ferox Copel) Tuber Extract and Fractions against T47D Breast Cancer Cells)}

\author{
Andi Nur Aisyah ${ }^{1}$, Syamsu Nur ${ }^{2 *}$, Endang Lukitaningsih ${ }^{3}$, Rumiyati ${ }^{3}$, Asril Burhan ${ }^{4}$, Syafia \\ Mustika Adjara ${ }^{4}$, Kurnia Rahim ${ }^{2}$ \\ ${ }^{1}$ Bagian Farmasetika, Sekolah Tinggi Ilmu Farmasi Makassar, 90242, Indonesia. \\ ${ }^{2}$ Bagian Kimia Farmasi, Sekolah Tinggi Ilmu Farmasi Makassar, 90242, Indonesia \\ ${ }^{3}$ Departemen Kimia Farmasi, Fakultas Farmasi Universitas Gadjah Mada, Yogyakarta, 55281, Indonesia \\ ${ }^{4}$ Bagian Biologi Farmasi, Sekolah Tinggi Ilmu Farmasi Makassar, 90242, Indonesia \\ *E-mail: syamsunur19@gmail.com
}

Article Info:

Received: 20 Agustus 2020

in revised form: 10 September 2020

Accepted: 20 September 2020

Available Online: 30 September 2020

\section{Keywords: \\ Paku Atai Merah \\ Cytotoxic \\ Breast Cancer \\ T47D Cell \\ MTT Assay}

Corresponding Author:

Syamsu Nur

Bagian Kimia Farmasi

Sekolah Tinggi Ilmu Farmasi

Makassar

90242

Indonesia

email: syamsunur19@gmail.com

\section{ABSTRACT}

The use of natural products has been widely used as a resource of new bioactive chemical compounds. One of them is the Paku Atai Merah (Angiopteris ferox Copel) tuber which has long been used empirically by the Dayak tribe of East Kalimantan as an anti-cancer. The purpose of this study was to determine the anticancer cytotoxic activity of the extract and fractions of Paku Atai Merah tuber against T47D breast cancer cells in vitro. Extract of Paku Atai Merah tubers was obtained by maceration method using ethanol solvent until obtained the ethanolic extract then fractionated using various solvents to obtain $n$-hexane, ethyl acetate, and aqueous-ethanol fractions. The cytotoxic effect was carried out based on the MTT assay. Phytochemical screening tests showed positive results for the presence of flavonoid, phenolic, tannin, saponin and steroid compounds. The results of the cytotoxic activity study showed that the ethyl acetate fraction had moderate cytotoxic activity in T47D cancer cells with an $\mathrm{IC}_{50}$ value of 84.8 $\mu \mathrm{g} / \mathrm{ml}$. Ethanol extract $(513.06 \mu \mathrm{g} / \mathrm{ml})$ and $\mathrm{n}$-Hexane frsction $(881.97 \mu \mathrm{g} /$ $\mathrm{ml}$ ) were also included in the weak category. This study indicates that ethyl acetate fraction can be developed as a supportive therapy for breast cancer treatment.

How to cite (APA $6^{\text {th }}$ Style):

Aisyah, A. N., Nur, S., Lukitaningsih, E., Rumiyati., Burhan, A., Syafia., Kurnia.. (2020). Efek Sitotoksik dari Ekstrak dan Fraksi Umbi Paku Atai Merah (Angiopteris ferox Copel) Terhadap Sel Kanker Payudara T47D. Jurnal Farmasi Galenika :Galenika Journal of Pharmacy (e-Journal), 6(2), 319-327. doi:10.22487/j24428744.2020.v6.i2.15255 


\begin{abstract}
ABSTRAK
Penggunaan bahan alam telah banyak digunakan sebagai sumber senyawa bioaktif baru. Salah satunya adalah umbi Paku Atai Merah (Angiopteris ferox copel) yang telah lama digunakan secara turun temurun oleh suku Dayak Kalimantan Timur sebagi anti kanker. Tujuan penelitian ini adalah untuk mengetahui aktivitas sitotoksik antikanker ekstrak dan fraksi umbi Paku Atai Merah terhadap sel kanker payudara T47D secara in vitro. Ekstrak umbi Angiopteris ferox Copel diperoleh dengan metode maserasi menggunakan pelarut etanol $96 \%$ kemudian difraksinasi menggunakan berbagai pelarut sehingga diperoleh fraksi n-Heksan, etil asetat, dan etanol-air. Uji aktivitas sitotoksik dilakukan berdasarkan metode MTT assay. Uji skrining fitokimia menunjukkan hasil yang positif pada senyawa golongan flavonoid, fenolik, tanin, saponin, dan steroid. Hasil penelitian aktivitas sitotoksik menunjukkan bahwa fraksi etil asetat memiliki aktivitas sitotoksik dengan kategori sedang pada sel kanker T47D dengan nilai $\mathrm{IC}_{50}(84,8$ $\mu \mathrm{g} / \mathrm{ml})$. Ekstrak etanol $(513,06 \mu \mathrm{g} / \mathrm{ml})$ dan fraksi $\mathrm{n}$-heksan $(881,97 \mu \mathrm{g} / \mathrm{ml})$ masuk dalam ketagori lemah. Berdasarkan pada hasil penelitian ini menunjukkan bahwa fraksi etil asetat dapat dikembangkan sebagai terapi suportif untuk pengobatan kanker payudara.
\end{abstract}

Kata kunci: Umbi Paku Atai Merah (Angiopteris ferox Copel), Sitotoksik, Kanker Payudara, Sel T47D, MTT

\title{
PENDAHULUAN
}

Kanker merupakan pertumbuhan yang tidak normal dari sel-sel jaringan tubuh yang berubah menjadi ganas (Kemenkes RI 2016). Kanker atau tumor ganas merupakan salah satu penyakit yang sampai saat ini masih belum dapat ditangani secara tuntas (Lis $d k k$., 2014). Berdasarkan data GLOBOCAN, international Agency for Research on Cancer (IARC), Pada tahun 2012, kanker menjadi penyebab kematian sekitar 8,2 juta orang. Kanker payudara menempati urutan kelima kematian akibat kanker secara keseluruhan dan sementara itu merupakan penyebab kematian yang paling sering terjadi pada perempuan (Kemenkes RI 2016). Kanker payudara merupakan gangguan dalam pertumbuhan sel normal mammae dimana sel abnormal timbul dari sel-sel normal berkembang biak dan menginfiltrasi jaringan limfe dan pembuluh darah (Humaera et al., 2017).

Pengobatan kanker pada umumnya dapat dilakukan dengan kombinasi dari metode operasi, penyinaran (radioterapi), obat penghambat sel kanker (sitostatika), obat peningkat daya tahan tubuh dan pengobatan dengan hormone (Anam et al., 2014). Terapi kanker dapat dilakukan dengan menghambat perkembangan atau membunuh sel kanker melalui pemacuan apoptosis (Fachreza, 2013) Pengobatan kanker pada pasien dengan menggunakan kemoterapi mempunyai efek samping yang sangat kuat (Utari K. $d k k$., 2013). Sehingga perlu dikembangkan obat-obatan antikanker yang rendahnya efek samping seperti obat-obatan yang berasal dari alam (Nurrochmad et al, 2011).

Penggunaan bahan alam sebagai obat kanker telah berlangsung sejak lama di hampir seluruh wilayah Indonesia salah satunya yaitu tumbuhan paku yang merupakan tumbuhan asli Indonesia yang memiliki banyak Khasiat (Arini and Kinho, 2012). Pada masyarakat Kutai Barat di Kecamatan Linggang Bigung Kalimantan Timur telah lama memberdayakan paku atai merah (Angiopteris ferox Copel) sebagai ramuan yang diduga memiliki potensi sebagai antikanker payudara dan sebagai antiracun. Bagian tanaman yang banyak digunakan berupa umbi, daun, batang, dan getah. Hasil analisis fitokimia ekstrak etanol umbi paku atai merah mengandung golongan senyawa kimia seperti flavonoid, alkaloid, tanin, saponin dan steroid. (Sundu $d k k ., 2018$ ).

Pada penelitian yang di lakukan oleh (Nur et al., 2019) menyatakan bahwa ekstrak etanol umbi paku atai merah (Angiopteris ferox Copel) memiliki kadar antioksidan yang kuat dengan nilai IC $_{50}$ sebesar 72,3 $\mu \mathrm{g} / \mathrm{mL}$. Selain itu, juga dilaporkan bahwa ekstrak etanol dari umbi paku atai merah memiliki efek toksik terhadap A.saline dengan metode BSLT. Senyawa yang berperan sebagai antioksidan dan efek toksik terhadap A.saline diantaranya flavonoid, alkaloid, tanin, dan juga fenolik. Salah satu senyawa antioksidan yang diduga memiliki aktivitas antikanker yaitu flavonoid yang bekerja dengan cara penghambatan inaktivasi karsinogenesis, inhibisi siklus sel, penghambatan angiogenesis, proliferasi sel dan mekanisme apoptosis (Burhan $d k k ., 2019)$. Berdasarkan latar belakang tersebut maka pada penelitian ini dilakukan 
pengujian aktivitas sitotoksik ekstrak paku atai merah (Angiopteris ferox Copel) terhadap sel T47D atau sel kanker payudara secara in vitro dengan metode MTT yang ditunjukkan dengan parameter nilai IC $_{50}$.

\section{METODE PENELITIAN}

\section{Alat dan Bahan}

Alat yang digunakan pada penelitian yang digunakan adalah tabung reaksi (Pyrex®), batang pengaduk, cawan porselin, gelas ukur (Pyrex®), erlemenyer, spatel, lampu spiritus, neraca analitik (Mettler Toledo), penjepit tabung, rak tabung, rotary evaporator (Buchi $\left.{ }^{\circledR}\right)$, Laminar Air Flow (Esco), haemocytometer (Neubauer), inkubator (Nescoß), mikroskop inverted (Olimpus), mikro pipet (Bio Rad), microplate 96 sumuran/well plate 96 (Iwaki), tabung eppendorf, ELISA reader (Thermo Fischer Scientific), vortex mixer (Heidolph), conical tube (Corning), tip mikropipet (Scilogex), botol duran, botol kultur / tissue culture flask (Nunclone) dan bejana maserasi.

Bahan-bahan yang digunakan pada penelitian ini yaitu umbi paku atai merah (Angiopteris ferox Copel), etanol 96\%, etil asetat, n-Heksan (One Med), aquades (One Med), aluminium foil,kertas lebel, media Dulbecco's modified eagle medium (DMEM) (Gibco), Dimethyl Sulfoxide (DMSO) (Merck), FBS (Fetal Bovine Serum) (Merck), MTT (3-(4,5-dimetiliazol-2-il)-2,5-difenil tetrazolium bromida) (Gibco), PBS (Phospate Buffered Salina), SDS (Sodium dodecyl sulphate) (Merck), Penisilin-streptomisin (Gibco), tripsin EDTA 0,25\% (Gibco), asam sulfat (Merck), pereaksi mayer, pereaksi dragendroff, pereaksi wagner, asetat anhidrat (Merck), serbuk magnesium, kloroform (JT-Baker), dan $\mathrm{FeCl}_{3} 1 \%$ (Emsure), asam klorida (Merck) dan sel uji yang digunakan untuk uji toksisitas adalah sel WiDr yang diperoleh dari stok Cancer Chemoprevention Research Center (CCRC) Fakultas Farmasi UGM.

\section{Metode}

\section{Penyiapan Sampel}

Sampel pada penelitian ini adalah umbi paku atai merah yang diperoleh di Kutai Barat Kecamatan Linggang Bigung Kalimantan Timur dengan kriteria adalah pada bagian umbi yang digunakan berumur kurang lebih 2 tahun. Umbi paku atai merah yang diperoleh kemudian dilakukan sortasi basah kemudian dicuci di bawah air mengalir. Ditiriskan agar sisa air cucian terbuang kemudian dilakukan perajangan agar proses pengeringan berlangsung lebih cepat dan disebarkan di atas kain sehingga air terserap. Simplisia dikeringkan dengan cara dijemur di bawah sinar matahari ditutup dengan kain hitam.

\section{Pembuatan Ekstrak}

Umbi paku atai merah yang telah dikumpulkan disortasi basah untuk memisahkan kotoran atau benda asing lainnya dari sampel, lalu dicuci menggunakan air mengalir dan ditiriskan. Setelah ditiriskan dilakukan perajangan lalu dikeringkan dengan cara ditempatkan di bawah sinar matahari dan ditutup kain hitam sampai kering. Simplisia yang telah kering disortasi kering dan diserbukkan. Simplisia kering yang telah diserbukkan sebanyak 1,2 Kg diekstraksi menggunakan pelarut etanol 96\% sebanyak 5 liter dengan metode maserasi. Simplisia dimasukkan ke dalam wadah maserasi kemudian ditambahkan pelarut secukupnya untuk proses pembasahan lalu didiamkan selama 15-30 menit. Sisa pelarut ditambahkan hingga semua simplisia terendam sempurna sambil sesekali diaduk selama 6 jam pertama, kemudian didiamkan di tempat yang terlindung dari cahaya matahari selama 3x24 jam. Hasil yang diperoleh dipisahkan antara residu dan filtrat. Residu diremaserasi kembali dengan pelarut yang sama seperti sebelumnya sampai cairan berwarna bening. Filtrat dikumpulkan kemudian diuapkan dengan rotary evaporator hingga diperoleh ekstrak kental.

\section{Fraksinasi dengan Metode Ekstraksi Cair-Cair}

Ekstrak kental umbi paku atai merah dilarutkan dalam campuran pelarut etanol:akuades (1:9). Campuran dimasukkan ke dalam corong pisah, kemudian ditambah pelarut n-heksan sebanyak $50 \mathrm{~mL}$, dikocok kuat dan didiamkan hingga terpisah sempurna. Fase n-Heksan kemudian dipisahkan dan fase etanol:akuades 
difraksinasi lagi dengan n-Heksan hingga larutan yang diperoleh bening. Fase etanol:air kemudian ditambahkan pelarut etil asetat sebanyak $50 \mathrm{~mL}$ dalam corong pisah. Campuran dikocok dan dibiarkan hingga terbentuk dua lapisan yaitu fase etil asetat berada pada bagian atas dan fase etanol:air berada pada bagian bawah. Kedua lapisan tersebut dipisahkan. Fase etanol:air yang diperoleh difraksinasi kembali menggunakan etil asetat hingga larutan yang diperoleh bening. Masing-masing filtrat hasil fraksinasi diuapkan sehingga diperoleh fraksi heksan, etil asetat dan etanol:air.

\section{Uji Aktivasi Penghambatan Sel Kanker T47D}

\section{Isolasi dan panen sel kanker panyudara (T47D)}

Pembuatan medium kultur dilakukan dengan mengacu pada metode (Doyle \& Bryan, 1998; Lee et al., 2012) yang telah dimodifikasi dengan mencampurkan media DMEM 10\% fetal bovie serum (FBS), $2 \mathrm{mM}$ glutamine, dan antibiotik (100 IU/ml penisilin dan $100 \mathrm{mg} / \mathrm{ml}$ streptomisin). Sel T47D yang diperoleh dari Cancer Chemopreventive Research Center (CCRC), dikultur pada media DMEM lengkap. Diamati pertumbuhan sel dan tiap 1 hari media diganti dengan media DMEM lengkap. Setelah sel memenuhi permukaan dish atau konfluen sekitar $>80 \%$, dilakukan panen sel. Sel yang menempel pada plate dicuci dengan media DMEM. Selanjutnya sel yang menempel pada dish dibilas dengan menggunakan larutan tripsin-EDTA dengan tujuan untuk melepaskan sel yang menempel pada dasar dish. Selanjutnya dish yang berisi sel diinkubasi pada suhu $37^{\circ} \mathrm{C}$ selama 5 menit dan diamati hingga sel tidak lagi menempel pada dish. Ditambahkan $5 \mathrm{ml}$ media lengkap pada dish untuk menginaktifkan tripsin. Selanjutnya suspensi dipindahkan pada conical tube dan disentrifugasi pada suhu ruang dengan kecepatan 1000rpm selama 10 menit. Supernatan dibuang, kemudian pellet diresuspensikan dengan $1 \mathrm{ml}$ media lengkap (Rittié and Fisher, 2005). Sebanyak 10 $\mu \mathrm{L}$ sel diambil dan ditransfer ke dalam hemocytometer dan sel dihitung dibawah mikroskop. Sejumlah sel diperlukan ditransfer ke dalam conical steril yang lain dan ditambah medium kultur sesuai dengan konsentrasi yang dikehendaki.

\section{Uji aktivitas proliferasi dengan MTT assay}

Sel yang telah dihitung $\left(2 \times 10^{4} \mathrm{sel} / \mathrm{sumuran}\right)$ kemudian didistribusikan pada sumuran sesuai jumlah ekstrak uji (1 sampai 1000 ppm), kontrol positif dan kontrol negatif. Kemudian campuran diinkubasi dalam inkubator yang dialiri $\mathrm{CO}_{2}$ pada suhu $37^{\circ} \mathrm{C}$ selama 24 jam untuk sel beradaptasi dan menempel di sumuran sampai sel siap untuk diberi perlakuan. Setelah akhir masa inkubasi, microplate yang berisi sel diambil dari inkubator kemudian dibuang media dengan cara microplate dibalikan di atas tempat buangan kemudian plate ditekan untuk meniriskan cairan. Larutan uji ekstrak yang telah diencerkan dengan media pada 5 seri konsentrasi yaitu $500 ; 250 ; 125 ; 62,5$; dan $31,25 \mu \mathrm{g} / \mathrm{mL}$ dan dimasukan dalam sumuran yang telah berisi sel T47D dimulai dari konsentrasi terkecil masing-masing sebanyak $100 \mu \mathrm{L}$, sedangkan pada sumuran kontrol negatif dimasukan media sesuai sel yang digunakan sebanyak $100 \mu \mathrm{L}$ kemudian microplate diinkubasi kembali dalam inkubator yang dialiri $\mathrm{CO}_{2}$ pada suhu $37^{\circ} \mathrm{C}$ selama 24 jam. Setelah akhir masa inkubasi, media sel dibuang kembali dan reagen MTT (3-(4,5-dimetiltiazol-2-il)-2,5-difenil tetrazolium bromida) konsentrasi $0,5 \mathrm{mg} / \mathrm{ml}$ disiapkan dengan cara sebanyak $1 \mathrm{~mL}$ larutan MTT $5 \mathrm{mg} / \mathrm{ml}$ ditambahkan media hingga $10 \mathrm{~mL}$. Larutan MTT didistribusikan ke dalam sumuran ekstrak uji, kontrol negatif dan blanko masing-masing $100 \mu \mathrm{L}$, microplate diinkubasikan kembali selama 4 jam dalam inkubator yang dialiri $\mathrm{CO}_{2}$ pada suhu $37^{\circ} \mathrm{C}$. Pada akhir inkubasi ditambahkan stopper SDS sebanyak $100 \mu \mathrm{L}$, didiamkan semalaman lalu serapan diukur dengan microplate reader pada panjang gelombang $595 \mathrm{~nm}$. Persentase sel hidup dihitung dari data serapan yang diperoleh (CCRC UGM, 2009; Nurrochmad et al, 2011)

\section{HASIL DAN PEMBAHASAN}

Uji aktivitas sitotoksik ekstrak etanol umbi paku atai merah (Angiopteris ferox Copel) terhadap sel kanker T47D secara in vitro dengan metode MTT (3-(4,5-dimetiltiazol-2-il)-2,5-difenil tetrazolium bromida) yang ditunjukkan dengan parameter nilai $\mathrm{IC}_{50}$ telah dilakukan. Tahapan penelitian dilakukan dengan proses 
pengolahan sampel, ekstraksi, fraksinasi, uji fitokimia kandungan senyawa dan pengujian aktivitas ekstrak etanol dan fraksi umbi paku atai merah.

\section{Skrining Fitokimia}

Skrining fitokimia merupakan salah satu cara yang dapat dilakukan untuk mengetahui potensi tanaman yang dapat digunakan dalam pengobatan. Pengujian ini dapat memberikan hasil terkait jenis golongan metabolit sekunder seperti alkaloid, flavonoid, fenolik, steroid, saponin dan triterpenoid. Tabel 3 menunjukkan bahwa umbi paku atai merah (Angiopteris ferox Copel) positif mengandung flavonoid, tanin, saponin, steroid dan fenolik. Berdasarkan penelusuran fitokimia yang telah dilakukan terhadap ekstrak dan fraksi umbi paku atai merah didapatkan hasil pada Tabel 1.

Tabel 1. Hasil uji skrining fitokimia dari esktrak dan fraksi umbi paku atai merah

\begin{tabular}{ccccc}
\hline Uji & $\begin{array}{c}\text { Ekstrak } \\
\text { Etanol }\end{array}$ & $\begin{array}{c}\text { Fraksi } \\
\text { n-heksan }\end{array}$ & $\begin{array}{c}\text { Fraksi } \\
\text { Etil Asetat }\end{array}$ & $\begin{array}{c}\text { Fraksi } \\
\text { Etanol-Air }\end{array}$ \\
\hline Alkaloid & - & - & + & - \\
Flavonoid & + & - & + & + \\
Tanin & + & - & + & + \\
Saponin & + & + & + & + \\
Steroid & + & + & + \\
Fenolik & + & + & + \\
\hline
\end{tabular}

Keterangan $:(+)=$ Mengandung senyawa, $(-)=$ Tidak terkandung senyawa

\section{Morfologi sel}

Bentuk morfologi sel merupakan salah satu ciri yang dapat dilihat ketika sel mengalami toksik ketika adanya perlakuan oleh adanya senyawa atau bahan kimia. Aktivitas sitotoksik sel kanker T47D juga dapat diamati secara mikroskopis untuk melihat morfologi kontrol sel T47D seperti pada gambar (A), morfologi sel T47D sebelum pemberian sampel pada gambar (B) dan morfologi sel T47D setelah pemberian sampel seperti pada gambar (C). Hasil pengamatan sel T47D menunjukkan adanya perbedaan morfologi sel sebelum dan setelah adanya perlakuan oleh senyawa.

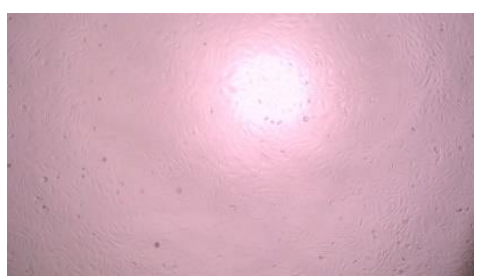

(A)



(C)

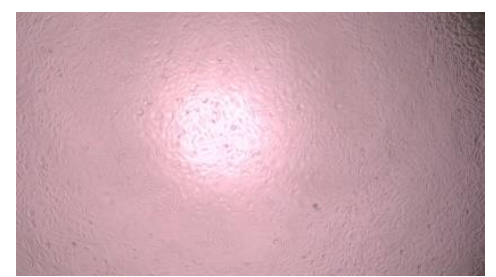

(B)

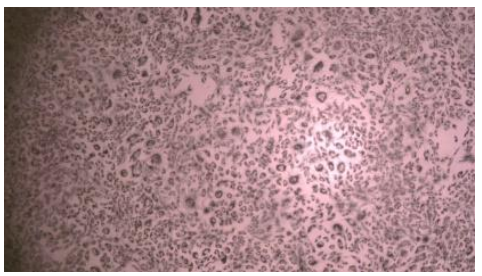

(D)

Gambar 1. Morfologi Kontrol Sel (A) Sel sebelum adanya perlakuan (B), setelah adanya perlakuan penambahan MTT pada kosentrasi sampel yang tinggi (C), setelah adanya perlakuan penambahan MTT pada kosentrasi sampel yang rendah (D). 
Hasil pengamatan sel T47D dapat dilihat pada gambar terdapat perbedaan morfologi pada sel sebelum dan sesudah penambahan ekstrak/fraksi dan reagen MTT. Pada gambar 1 dapat dilihat pada bagian C dimana sel dengan konsentrasi tinggi terbentuk kristal formazan yang relative sedikit di bandingkan dengan bagian D yang memiliki konsentrasi rendah terbentuk Kristal formazan yang lebih banyak. Hal ini menunjukkan bahwa semakin tinggi konsentrasi maka kristal formazan yang terbentuk semakin sedikit artinya semakin sedikit sel yang hidup. Hal ini terjadi karena sel - sel yang mati akibat perlakuan ekstrak/fraksi, kemungkinan besar tidak memiliki enzim mitokondria reduktase sehingga pada saat penambahan reagen MTT tidak mengalami perubahan menjadi kristal formazan (tetap berwarna kuning). Menurut (Kalantzi \& Biskos, 2014) kristal formazan tersebut berbentuk kristal tajam yang berwarna hitam.

\section{Uji Aktivitas sitotoksik dengan metode MTT assay}

Uji sitotoksisitas merupakan uji untuk mengetahui kemampuan suatu ekstrak dan fraksi dalam memberikan efek toksik pada sel dengan konsentrasi tertentu. Salah satu metode umum yang digunakan untuk sitotoksisitas secara in vitro adalah metode MTT. Uji MTT adalah uji kolorimetri untuk mengukur aktivitas metabolisme sel hidup yang dilakukan dengan menambahkan sampel ke dalam setiap well lalu di inkubasi selama 4 jam, pada saat inkubasi MTT yang berwarna kuning dengan kemampuan nikotinamid adenin dinukleotida fosfat (NADPH) - dependen Enzim oksidoreduktase seluler untuk mengurangi MTT sehingga sel menjadi kristal formazan berwarna ungu. Oleh karena itu uji ini digunakan untuk mengukur viabilitas sel dalam hal aktivitas reduktif sebagai konversi enzimatik dari senyawa tetrazolium untuk air kristal formazan tidak larut oleh dehidrogenase yang terjadi di mitokondria (V. Kuete et al., 2017). Pada uji sitotoksisitas dibuat larutan uji mengunakan ekstrak dan fraksi umbi paku atai merah serta doxorubicin sebagai kontrol positif. Doxorubicin merupakan obat agen antikanker yang digunakan untuk pengobatan berbagai macam jenis kanker seperti kanker payudara, leukimia akut, kanker tulang dan kanker ovarium (CCRC, 2014). Oleh karena itu pada uji sitotoksisitas doxorubicin digunakan sebagai kontrol positif.
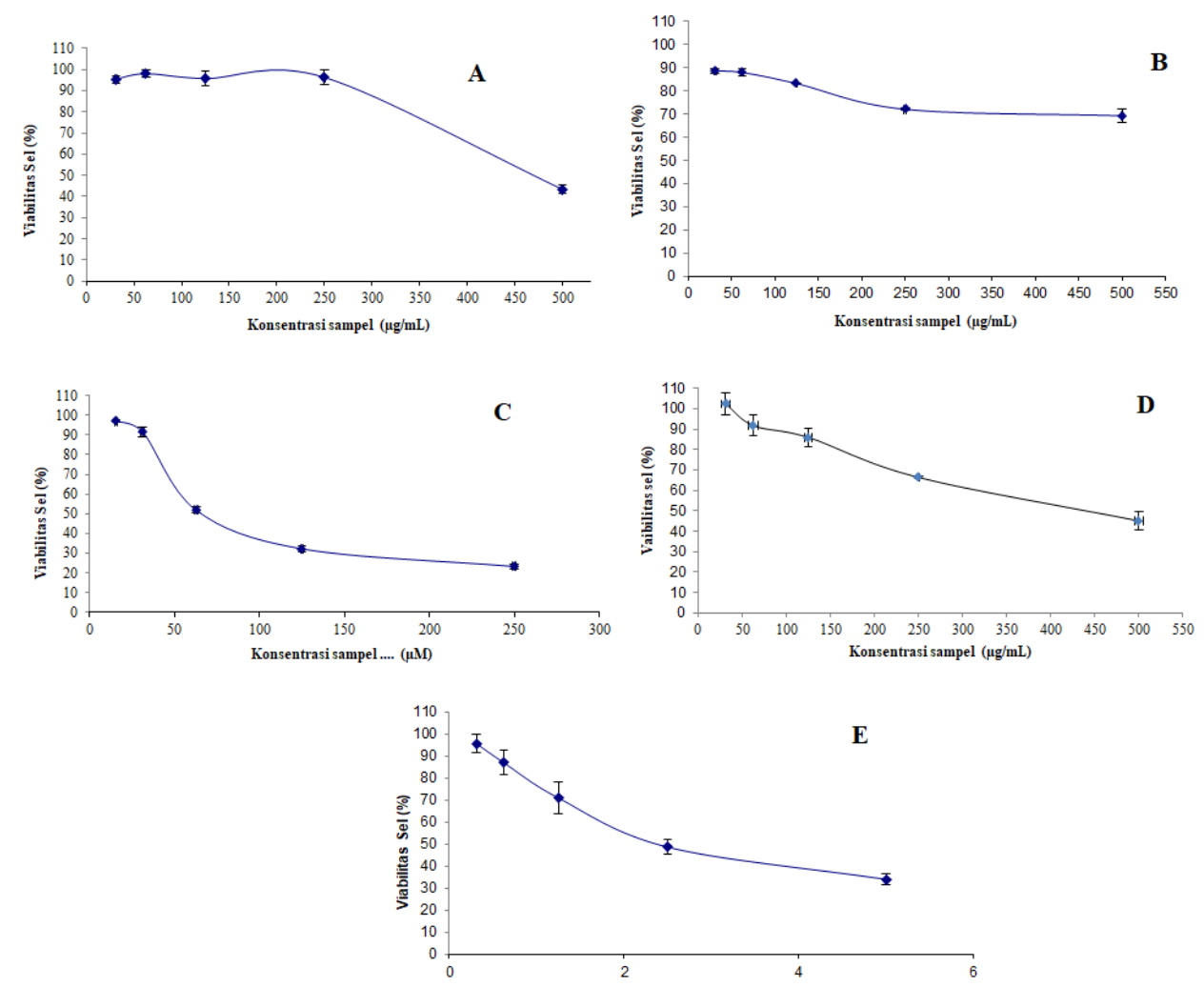

Gambar 2. Grafik hubungan antara persentase viabilitas sel kanker T47D terhadap konsentrasi masing-masing sampel. (A) Ekstrak etanol, (B) Fraksi n-Heksan, (C) Fraksi etil asetat, (D) Fraksi etanol air dan (E) Kontrol positif. Perlakuan dilakukan triplikasi $(n=3)$ 
Gambar 2 merupakan grafik hubungan antara persen viabilitas sel T47D terhadap konsentrasi masingmasing sampel uji. Aktivitas sitotoksik ekstrak dan fraksi umbi paku atai merah terhadap sel Hela tergantung dari konsentrasi yang digunakan, semakin tinggi konsentrasi larutan uji maka semakin sedikit kandungan kristal formazan yang terbentuk maka viabilitas sel semakin rendah artinya semakin sedikit sel hidup. Berdasarkan hal tersebut diperoleh korelasi antara larutan uji dengan efek sitotoksik yang menunjukkan pola dose dependent, yaitu semakin tinggi konsentrasi maka semakin kecil persen viabilitas sel (Ismiyati \& Nurhaeni, 2016).

Tabel 2. Nilai $\mathrm{IC}_{50}$ dari ekstrak dan fraksi terhadap sel T47D

\begin{tabular}{|c|c|c|c|c|c|c|}
\hline \multirow{2}{*}{ Sampel } & \multicolumn{5}{|c|}{ Konsentrasi $(\mu \mathrm{g} / \mathrm{mL})$} & \multirow{2}{*}{$\mathrm{IC}_{50}$} \\
\hline & 31,25 & 62,5 & 125 & 250 & 500 & \\
\hline Ekstrak & $95,32 \pm 1,68$ & $97,97 \pm 1,94$ & $95,68 \pm 3,40$ & $96,20 \pm 3,47$ & $43,35 \pm 2,19$ & $513,06 \pm 4,26$ \\
\hline Fraksi Heksan & $88,65 \pm 0,99$ & $88,02 \pm 1,70$ & $83,27 \pm 0,15$ & $72,12 \pm 0,54$ & $69,32 \pm 3,06$ & $881,97 \pm 8,11$ \\
\hline Fraksi Etil Asetat & $97,95 \pm 0,78$ & $91,50 \pm 2,29$ & $51,86 \pm 1,41$ & $32,13 \pm 1,75$ & $23,13 \pm 1,08$ & $84,81 \pm 1,92$ \\
\hline Fraksi Air-etanol & $98,83 \pm 1,57$ & $91,73 \pm 5,24$ & $85,90 \pm 4,32$ & $66,35 \pm 0,66$ & $45,02 \pm 4,43$ & $434,41 \pm 1,61$ \\
\hline Doxorubisin & \multicolumn{6}{|c|}{$\mathrm{IC}_{50}(\mu \mathrm{g} / \mathrm{mL})=3,13 \pm 1,29$} \\
\hline
\end{tabular}

Data hasil persen penghambatan dan nilai $\mathrm{IC}_{50}$ dari masing-masing sampel diekspresikan dalam bentuk mean $\pm \mathrm{SD}$ $(n=3)$.

Pada uji sitotoksisitas secara kuantitatif dibutuhkan nilai $\mathrm{IC}_{50}$, nilai $\mathrm{IC}_{50}$ menunjukkan konsentrasi yang dibutukan untuk dapat menghambat pertumbuhan sel kanker T47D sebesar 50\% dari total populasi. Semakin kecil nilai $\mathrm{IC}_{50}$ maka semakin besar aktivitas sitotoksiknya. Penentuan nilai $\mathrm{IC}_{50}$ dihitung berdasarkan regresi linear antara konsentrasi ekstrak dan fraksi umbi paku atai merah (Angiopteris ferox Copel) dengan persen viabilitas sel. Tabel 2 merupakan hasil penelitian aktivitas sitotoksik yang menunjukkan bahwa fraksi etil asetat memiliki aktivitas sitotoksik pada sel kanker T47D dengan nilai IC $_{50}$ $(84,81 \pm 1,92 \mu \mathrm{g} / \mathrm{ml})$ dengan kategori sedang diikuti oleh fraksi etanol air $(434,41 \pm 1,61 \mu \mathrm{g} / \mathrm{ml})$, ekstrak etanol $(513,06 \pm 4,26 \mu \mathrm{g} / \mathrm{ml})$ dan fraksi $\mathrm{n}-$ Heksan $(881,97 \pm 8,11 \mu \mathrm{g} / \mathrm{ml})$ yang dikategorikan dengan aktivitas lemah. Sementara itu, nilai $\mathrm{IC}_{50}$ dari kontrol positif doxorubicin diperoleh nilai $\mathrm{IC}_{50}$ sebesar $3,13 \pm 1,29$ $\mu \mathrm{g} / \mathrm{mL}$ yang termasuk dalam kategori sitotoksik kuat. Menurut Kuete et al (2017), Nilai $\mathrm{IC}_{50}<50 \mu \mathrm{g} / \mathrm{mL}$ dikategorikan memiliki efek sitotoksik kuat, jika nilai $50-<200 \mu \mathrm{g} / \mathrm{mL}$ dikategorikan sitotoksik sedang, dan nilai $200 \mu \mathrm{g} / \mathrm{mL}-<1000 \mu \mathrm{g} / \mathrm{mL}$ dikategorikan memiliki efek sitotoksik lemah dan nilai $\mathrm{IC}_{50}>1000$ $\mu \mathrm{g} / \mathrm{mL}$ tidak memiliki efek sitotoksik. Berdasarkan pada hasil penelitian yang menunjukkan bahwa fraksi etil asetat memberikan efek sitotoksik dengan aktivitas sedang. Hal tersebut menunjukkan bahwa fraksi etil asetat memiliki aktivitas yang lebih baik jika dibandingkan dengan lainnya sehingga perlu dilakukan penelusuran lebih lanjut senyawa yang bertanggung jawab.

Beberapa teori yang melaporkan bahwa beberapa golongan senyawa yang berkhasiat sebagai anti kanker seperti flavonoid dan saponin. Flavonoid dapat sebagai anti kanker melalui mekanisme pengaktifan jalur apoptosis sel kanker melalui proses fragmentasi pada DNA. Fragmentasi ini terjadi melalui pelepasan rantai proksimal DNA oleh senyawa radikal seperti radikal hidroksil. Selain itu, flavonoid juga bekerja dengan menghambat aktivitas protein kinase sehingga jalur transduksi sinyal dari membran ke sel inti akan terhambat (Woo \& Kim, 2013). Selain itu, senyawa tanin memiliki efek antikanker, dengan mekanisme pengaktifan jalur apoptosis sel kanker akibat fragmentasi DNA (Meiyanto $d k k$., 2008). Senyawa saponin juga diketahui dapat berpotensi sebagai antikanker dengan menghambat pembentukan Bcl-2 yang diekspresikan terlalu tinggi, menginduksi protein caspase-3 yang diekspresikan terlalu rendah, meningkatkan ekspresi p53, dan dapat pula memicu G1 cellcycle arrest (Raju et al., 2004). Berdasarkan hal tersebut, sehingga fraksi etil asetat memungkinkan dilakukan pencarian senyawa baru yang dapat dikembangkan sebagai terapi suportif untuk pencegahan dan pengobatan penyakit kanker payudara. 


\section{KESIMPULAN}

Ekstrak dan fraksi dari umbi paku atai merah (Angiopteris ferox Copel) diperoleh hasil screening fitokimia mengandung fenolik, flavonoid, steroid, tanin dan saponin. Berdasarkan hasil aktivitas sitotoksik dari ekstrak dan fraksi umbi paku atai merah terhadap sel kanker line T47D diperoleh hasil bahwa fraksi etil asetat memberikan efek sitotoksik yang sedang jika dibandingkan dengan ekstrak dan fraksi lainnya sehingga hasil penelitian ini dapat mendukung pencarian senyawa baru yang memiliki aktivitas sebagai anti kanker payudara.

\section{UCAPAN TERIMAKSIH}

Penulis mengucapkan terimakasih kepada Kementrian Pendidikan dan Kebudayaan Republik Indonesia yang memberikan bantuan dana penelitian melalui hibah penelitian kerjasama perguruan tinggi.

\section{DAFTAR PUSTAKA}

Anam, S., Ritna, A., \& Dwimurti, F. (2014). Aktivitas Sitotoksik Ekstrak Metanol Benalu Batu ( Begonia sp .): Ethnomedicine Suku Wana Sulawesi Tengah ( Cytotoxic Activity of Benalu Batu (Begonia sp .) Methanolic Extract: An Ethnomedicine of Wana Tribe Central Sulawesi ). 12(1), 10-16.

Arini, D. I. D., \& Kinho, J. (2012). The pteridophyta diversity in Gunung Ambang Nature Reserve North Sulawesi. Info BPK Manado, 2(1), 17-40.

Burhan, A., Aisyah, A. N., Awaluddin, A., Zulham, Z., Taebe, B., \& Gafur, A. (2019). Uji Aktivitas Antioksidan Dan Antikanker Ekstrak Batang Murbei (Morus Alba L.) Terhadap Sel Kanker Widr Secara in Vitro. Kartika : Jurnal Ilmiah Farmasi, 7(1), 17. https://doi.org/10.26874/kjif.v7i1.173

CCRC UGM. (2009). Prosedur tetap. Uji Kombinasi Dengan Agen Kemoterapi. https://doi.org/10.1109/ICSMC.2011.6084006

Doyle, A., \& Bryan, G. J. (1998). Cell and tissue culture: laboratory procedure in biotechnology. In CEUR Workshop Proceedings. https://doi.org/10.1017/CBO9781107415324.004

Fachreza Erdi Pratama, R. F. N. (2013). Farmaka. Review: Senyawa Aktif Antikanker Dari Bahan Alam Dan Aktivitasnya, 4, 1-15.

Humaera, R., Mustofa, S., Kedokteran, F., \& Lampung, U. (2017). Diagnosis dan Penatalaksanaan Karsinoma Mammae Stadium 2 Diagnosis and Management of Breast Cancer Stage 2. Journal Psikologi, 7(April), 103-107.

Ismiyati, N., \& Nurhaeni, F. (2016). The Effect of Ocimum sanctum L . Leaves Ethanolic Extract as A Chemopreventive Agent in HeLa Cervic Cancer Cells Through Cytotoxic Activity and Induced Apoptosis. Media Farmasi.

Kalantzi, O. I., \& Biskos, G. (2014). Methods for assessing basic particle properties and cytotoxicity of engineered nanoparticles. In Toxics. https://doi.org/10.3390/toxics2010079

Kemenkes Ri 2016. (n.d.). InfoDatin Bulan Peduli Kanker Payudara_2016.pdf.

Kuete, V., Karaosmanoğlu, O., \& Sivas, H. (2017). Chapter 10 - Anticancer Activities of African Medicinal Spices and Vegetables (V. B. T.-M. S. and V. from A. Kuete (ed.); pp. 271-297). Academic Press. https://doi.org/https://doi.org/10.1016/B978-0-12-809286-6.00010-8

Lee, H.-J., Lee, J.-Y., Song, K.-C., Kim, J.-H., Park, J.-H., Chun, K.-H., \& Hwang, G.-S. (2012). Protective Effect of Processed Panax ginseng, Sun Ginseng on UVB-irradiated Human Skin Keratinocyte and Human Dermal Fibroblast. Journal of Ginseng Research, 36(1), 68-77. 
https://doi.org/10.5142/jgr.2012.36.1.68

Lis, N., Kinho, J., \& Tabba, S. (2014). kandungan bahan aktif dan toksisitas tumbuhan hutan asal sulawesi utara yang berpotensi sebagai obat ( Active Ingredients and Their Toxicity of Several Forest Plant Species Indigenous from North Sulawesi Potential as Efficacious Medicine ). Journal of Forest Products Research, 32(2), 123-124.

Meiyanto, E., Susidarti, R. A., \& Handayani, S. (2008). Ekstrak Etanolik Biji Buah Pinang ( Areca catechu L .) mampu menghambat proliferasi dan memacu apoptosis sel MCF-7 Ethanolic extract of Areca catechu seeds inhibit prolifera-. Majalah Farmasi Indonesia,.

Nur, S., Mubarak, F., Jannah, C., Winarni, D. A., Rahman, D. A., Hamdayani, L. A., \& Sami, F. J. (2019). Total phenolic and flavonoid compounds, antioxidant and toxicity profile of extract and fractions of paku atai tuber (Angiopteris ferox Copel). Food Research, 3(6). https://doi.org/10.26656/fr.2017.3(6).135

Nurrochmad et al. (2011). Anti cancer activity of rodent tuber (Thyphonium flagelliforme (lodd.) Blume on human breast cancer t47d cells . International Journal of Phytomedicine 3 (2011) 138-146. 3, 138146.

Raju, J., Patlolla, J. M. R., Swamy, M. V., \& Rao, C. V. (2004). Diosgenin, a steroid saponin of Trigonella foenum graecum (Fenugreek), inhibits azoxymethane-induced aberrant crypt foci formation in F344 rats and induces apoptosis in HT-29 human colon cancer cells. Cancer Epidemiology Biomarkers and Prevention.

Rittié, L., \& Fisher, G. J. (2005). Isolation and culture of skin fibroblasts. Fibrosis Research: Methods and Protocols, 83-98.

Sundu, Reksi, \& Handayani, F. (2018). uji aktivitas antibakteri ekstrak etanol umbi paku atai merah (Angiopteris ferox Copel) terhadap Propionibacterium acnes. Jurnal Medical Sains, 2(2), 75-82.

Utari K., E. N. tri, A., I. S., , Rafi ka Sari., W. A. K., \& Harti, A. (2013). Kegunaan Daun Sirsak ( Annona Muricata L ) untuk Membunuh Sel Kanker dan Pengganti Kemoterapi. KesMaDaSka, 1-6.

Woo, H. D., \& Kim, J. (2013). Dietary flavonoid intake and risk of stomach and colorectal cancer. World Journal of Gastroenterology. https://doi.org/10.3748/wjg.v19.i7.1011 